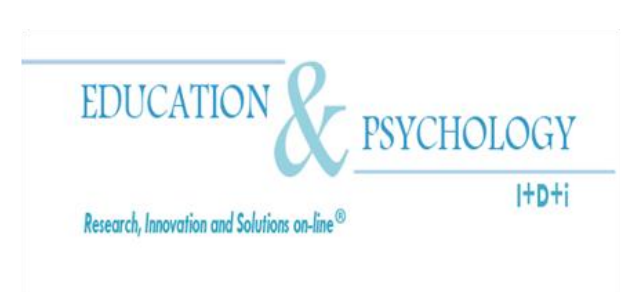

\title{
An Examination of Attachment Styles and Social Skills of University Students
}

\author{
Esra Dereli ${ }^{1}$ and Özlem Karakuş ${ }^{2}$ \\ ${ }^{1}$ Department of Pre School Education, University of Eskisehir Osmangazi \\ ${ }^{2}$ Department of Social Work, University of Selcuk

\section{Turkey}

Correspondence: Esra Dereli, ${ }^{1}$ Department of Preschool Education, University of Eskisehir Osmangazi, Eskisehir, Turkey. E- mail: esdereli@hotmail.com

C) Education \& Psychology I+D+i and Editorial EOS (Spain) 


\begin{abstract}
Introduction. Attachment organization across the lifespan and across generations, long-term predictions from attachment organization to later psychosocial functioning, and the possibility of altering attachment organization with intervention suggest that attachment theory may potentially shed valuable light on adult social development and deviant behavior. In this article are planned that to examine social skills and attachment styles of university students in Turkey.
\end{abstract}

Method. A sample of 343 university students completed measures of Relationships Scale Questionnaire and Social Skills Inventory. To analyze data, correlation analysis, and regression analysis were employed.

Results. Result indicated that secure attachment and social skills are related on several significant dimensions. Regression analyses indicated that a significant effect of attachment styles on social skills was detected. There found positive significant relation between secure attachment style and emotional expressivity, emotional sensitivity, emotional control, social expressivity and social control scores. There found a negative relation between fearful attachment style scores and social control and emotional expressivity scores and a positive relation between fearful attachment style and social sensitivity scores. No significant relation was found between other attachment styles and social skills scores. It was found out that secure attachment style predicted emotional expressivity, emotional sensitivity, social expressivity, and social control skills. It was also found that fearful and dismissing attachment style predicted emotional sensitivity skill, and preoccupied attachment style predicted social control.

Discussion and Conclusion. As a result of the study, there found a significant relation between attachment styles and social skills of students attending education faculty and it was determined that attachment styles predicted social skills. Considering this case, teacher trainees can be trained to raise their awareness about attachment styles and development of social skills. Especially, pre-school and elementary teacher candidates can be trained to set a good role model for their prospective students.

Key Words: Attachment Style, Social Skills, University Students, University Education. 


\section{Un Examen de los Estilos de Apego y Habilidades Sociales de los Estudiantes Universitarios}

\section{Resumen}

Introducción. La organización del apego a través de toda la vida y de las generaciones, las predicciones a lo largo plazo de la organización del apego al posterior funcionamiento psicosocial y la posibilidad de alterar la organización de apego con la intervención sugieren que la teoría de apego potencialmente podría arrojar valiosa luz sobre el desarrollo social de los adultos y la conducta desviada. Este estudio pretende investigar el estilo de apego y las habilidades sociales de los estudiantes universitarios en Turquía.

Método. En el estudio participaron 343 estudiantes universitarios y las mediciones se llevaron a cabo mediante una encuesta de la escala de relación y el inventario de habilidades sociales. En el análisis de datos, se utilizaron análisis de correlación y análisis de regresión.

Resultados. Se encontraron relaciones significativas entre el apego seguro y algunas dimensiones inferiores de habilidades sociales. Según el análisis de regresión, se determinó que los estilos de apego tienen una influencia significativa en las habilidades sociales. Se determinó que existe una relación positiva significativa entre el estilo de apego seguro y el expresionismo afectivo, la sensibilidad afectiva, el control afectivo, el expresionismo social y punto de control social. Entre el estilo de apego ansioso y el control social y puntos del expresionismo afectivo, una relación negativa significativa y entre el estilo de apego ansioso y puntos de sensibilidad social, se encontró una relación positiva significativa. Entre los otros estilos de apego y puntos de habilidades sociales no se encontró ninguna relación. Se encontró que el estilo de apego seguro predice el expresionismo afectivo, la sensibilidad afectiva, el expresionismo social y las habilidades de control social. Resultó que el estilo de apego seguro predice el expresionismo afectivo, la sensibilidad afectiva, el expresionismo social y las habilidades de control social. Además se encontró que el estilo de apego ansioso y desdeñoso predice la habilidad de sensibilidad social y el estilo de apego obsesivo predice el control social.

Discusión y conclusiones. Como resultado de este estudio, una relación significativa entre los estilos de apego y las habilidades sociales de los estudiantes de la Facultad de Educación y se determinó que los estilos de apego predicen las habilidades sociales. Teniendo en cuenta esta 
circunstancia, la educación recibida por los futuros profesores podría crear conciencia del desarrollo de habilidades sociales y estilos de apego. Especialmente los maestros practicantes de escuela primera y preescolar tienen que ser educados para ser un buen modelo para los alumnos a quienes educan.

Palabras clave: Estilo de apego, habilidades sociales, estudiante universitario, educación universitaria. 


\section{Introduction}

Once a baby is born, he/she needs the existence of an adult to protect it and to meet its basic needs and the need for love. The person who meets its needs is generally the mother who gave birth to the child and brings it up (Ainsworth, 1967). The sensitivity of mother towards her baby (meeting her needs on time), her approachability, acceptance of her baby, her communication with the baby and reactivity (Posada, Carbonell, Alzate \& Plata, 2004), lead to the formation of an emotional connection between mother and baby (Ainsworth, 1967). Bowlby called this emotional connection between the mother and the child as attachment. Attachment is defined as emotional connections people develop towards individuals who they regard to be important for themselves (Bowlby, 1973, 1980).

According to Bowlby (1973), children internalize their connection experiences with their mothers and these early experiences direct the child's relations later. These connections makes it easier internal representations or alias their own and others 'models which help individuals to understand and predict their environment which include vital conditions such as feeling of psychological security and maintaining closeness (Bretherton, 1985). This first sample internalized later forms the basis for relations in the future (Bartholomew \& Horowitz, 1991; Shaver \& Fraley, 2000). Ainsworth (1989) states that the attachment styles which are shaped with relation babies develop with their parents will generally be repeated in close relation they will develop when they grow up.

Hazan \& Shaver (1987) conceptualized romantic attachment as an attachment style and argued that three attachment styles in childhood can reappear in adolescence and adulthood in romantic and marriage relations and developed a simple scale based Ainsworth ' s definitions of three child attachment styles (Cooper, Shaver \& Collins, 1998). Another important contribution to adult attachment styles was made by Bartholomew \& Horowitz (1991). They developed four styles of attachment model to explain self and attachment figure model. According to this model, people have a working model towards themselves as well as towards other people. Four attachment styles are obtained from the crossing of positive and negative mental representations of self and others (Bartholomew \& Horowitz, 1991).

Secure individuals are generally happy with their relations and they have the feeling of accepted by others. They think that other people are favorable, trustworthy and are worth 
being loved (Feeney, 1998; Burger, 2006). As these individuals find other people worth loving, reliable and altruistic (Collins \& Read, 1990), they tend to relax by receiving support from others when they come across a problem (cited in Kart, 2002). Lieberman (1977) observed that while the children who attach their mothers safely tend to display behaviors like being more sharing, providing social support and display less negative behaviors such as physical-verbal assault, crying Preoccupied individuals are not confident. Their opinions about people are negative and they have conflicts in their relations (Collins, 1996). Fearful individuals have low self-confidence and do not ask for help form others when they experience stress because they do not trust others (Sümer \& Güngör, 1999; Bartholomew \& Horowitz, 1991). Dismissing type has difficulty in telling their problems to others as they do not trust others (Bartholomew \& Horowitz, 1991).

Attachment theory has led to great strides in understanding the development of social behavior and psychopathology in infancy and early childhood, however, attachment styles impact of social development begins to be seen in adolescence and adulthood. A broad array of findings including demonstrated continuities in attachment organization across the lifespan and across generations, long-term predictions from attachment organization to later psychosocial functioning, and the possibility of altering attachment organization with intervention suggest that attachment theory may potentially shed valuable light on adult social development and deviant behavior ( Bowlby, 1969, 1982)

Riggio (1986) divides social skill into six dimensions as emotional expressivity, emotional sensitivity, emotional control, social expressivity, social sensitivity and social control. Emotional expressivity refers to the skills of individuals to express their non-verbal communication skills, especially skills of sending emotional messages, in expressing the direction of non-verbal expression in interpersonal communication and emotional conditions fully, emotional sensivity in receiving, understanding and interpreting others ' non-verbal messages; emotional control in arranging and controlling their emotional and non-verbal reactions. Social expressivity refers to the skills of an individual to express their skills in social communication and in engaging in communication, social sensivity receiving, understanding and interpreting others verbal communications (social sensitivity), social control playing social roles and social expression, behaving appropriate to any social occasion, being self-confident and being able to easily adapt to any social occasion. Human beings interact with his/her environment by developing social relations. In the process of 
interaction, people can only develop robust relations by acquiring social skills adequately (Deniz, 2002).

Questions of this study

Cassidy, Kirsh and Scolton (1996) stated that social skills are related with each other and attachment styles are a good predictor of social skills. Based on these statements, in this study the relation between students, attachment styles and social skill scores and whether attachment styles predict social skill scores was examined. With this in mind, answers for the following questions were sought.

1. Is there a significant relation between attachment styles and social skill scores?

2. Do their attachment styles explain their social skill scores?

\section{Method}

\section{Participants}

The study was designed in survey model to determine the relation between attachment styles and social skill scores and the explanatory power of attachment styles for social skills. The study group is composed of 343 voluntary students randomly chosen among students at Education Faculty of Selcuk University. The students' age mean is 20.

\section{Instruments}

Social Skills Inventory (SSI): The SSI developed by Riggio (1986), revised by Riggio (1989), and adapted to Turkish participants by Yüksel (1997) was used to obtain data related to the social skills of participants. The SSI is a 90 items Likert type inventory of self-report to measure basic social skills. The SSI consists of six subscales. Reliability studies of SSI were performed by the Retst Method and the reliability coefficients for subscales varied between .80 and .89 . The Cronbach' s Alpha Reliability Coefficient of the social skill subscales varied between .56 and .82 . In the validation of the scale, similar scales validation was applied and Self- Regulation scale developed by Synder and adapted into Turkish by Bacanl1 (1990) was used. There found a correlation of .63 between the scores from the scales. Besides, experts stated that the scale could measure social scales (Ekinci, 2006). 
Relationships Scales Questionnaire (RSQ): The RSQ developed by Griffin and Bartholomew (1994) and adapted to Turkish participants by Sumer and Güngör (1999). The RSQ is a 17 items Likert type scale measure four different attachment styles (secure, dismissing, fearful, and preoccupied). The reliability coefficients of the scale were calculated by the Retst Method and varied between .54 and .78. The parallel form validity of this scale was tested with the Relationship Questionnaire (Bartholomew \& Horowitz, 1991) and the correlation coefficients varied between .49 and .61( Sumer and Güngör, 1999).

\section{Procedure}

Attachment Styles and Social Skills Scales were applied to various parts of Selcuk University Faculty of Education. The research is survey model. The survey took approximately 20 minutes to complete. The study group is composed of 343 voluntary students randomly chosen among students.

\section{Statistical Analyze}

Multiple Varible Regression Analysis, Pearson Correlation Coefficients were employed to analyze the data obtained by inventories used in the research. The SPSS 11.0 package was used in the analysis of data.

\section{Results}

In the study, first of all the relation between attachment styles and social skill, later on whether attachment styles explained social skill scores was examined and the results are given below.

Table 1. The Relation between Attachment Styles and Social Skill Scores

\begin{tabular}{ccccccc}
\hline Attachment & $\begin{array}{c}\text { Emotional } \\
\text { Expressivity }\end{array}$ & $\begin{array}{c}\text { Emotional } \\
\text { Sensitivity }\end{array}$ & $\begin{array}{c}\text { Emotional } \\
\text { Control }\end{array}$ & $\begin{array}{c}\text { Social } \\
\text { Expressivity }\end{array}$ & $\begin{array}{c}\text { Social } \\
\text { Sensitivity }\end{array}$ & $\begin{array}{c}\text { Social } \\
\text { Control }\end{array}$ \\
\hline Secure &, $248^{* * *}$ &, $314 * * *$ &, $111^{*}$ &, $308 * * *$ &,- 041 &, $378^{* * *}$ \\
Fearful &,$- 166^{* *}$ &, 005 &, 005 &,- 101 &, $127 *$ &,$- 173 * * *$ \\
Dismissing &, 039 &, 103 &, 065 &, 005 &, 087 &,- 056 \\
Preoccupied &,- 002 &, 009 &,- 038 &,- 013 &, 089 &,- 085 \\
\hline$* * * \mathrm{p}<.001, * *$ & $\mathrm{p}<.01, * \mathrm{p}<.05$ & & & & &
\end{tabular}

When the table is examined, it is seen that there is a positive significant relation between students' secure attachment styles scores and emotional expressivity, emotional sensitivity, social 
expressivity, social control scores ( $\mathrm{p}<.001)$. In a similar way, there found a significant positive relation between secure attachment style and emotional control scores $(\mathrm{p}<.01)$. There found negative significant relation between fearful attachment style scores and social control scores $(p<.001)$. There found negative significant relation between fearful attachment style scores and emotional expressivity scores $(\mathrm{p}<.01)$, and positive significant relation between social sensitivity $(\mathrm{p}<.05)$. There found no relation between dismissing, preoccupied attachment style scores and emotional expressivity, emotional sensitivity, emotional control, social expressivity, social sensitivity, social control scores $(\mathrm{p}>05)$.

Table 2. Explanatory and Predictive Powers of Attachment Styles for Social Skills

\begin{tabular}{|c|c|c|c|c|c|}
\hline Dependent Variable & $\mathbf{R}^{2}$ & $\bar{F}$ & Attachment Styles & $\bar{\beta}$ & $\bar{t}$ \\
\hline Emotional Expressivity & ,075 & $6,882 * * *$ & $\begin{array}{l}\text { Secure } \\
\text { Fearful } \\
\text { Dismissing } \\
\text { Preoccupied }\end{array}$ & $\begin{array}{l}.389 \\
.135 \\
.121 \\
-.053\end{array}$ & $\begin{array}{l}3,893 * * * \\
-1,623 \\
1,604 \\
-, 339\end{array}$ \\
\hline $\begin{array}{l}\text { Emotional } \\
\text { Sensitivity }\end{array}$ &, 135 & $13,203 * * *$ & $\begin{array}{l}\text { Secure } \\
\text { Fearful } \\
\text { Dismissing } \\
\text { Preoccupied }\end{array}$ & $\begin{array}{l}.150 \\
.056 \\
.067 \\
-.061\end{array}$ & $\begin{array}{l}6,953 * * * \\
2,384 * \\
2,328 * \\
-1,016\end{array}$ \\
\hline Emotional Control &, 024 & 2,059 & & & \\
\hline $\begin{array}{l}\text { Social } \\
\text { Expressivity }\end{array}$ &, 100 & $9,461^{* * *}$ & $\begin{array}{l}\text { Secure } \\
\text { Fearful } \\
\text { Dismissing } \\
\text { Preoccupied }\end{array}$ & $\begin{array}{l}.332 \\
.026 \\
.037 \\
-.062\end{array}$ & $\begin{array}{l}5,811 * * * \\
, 450 \\
, 703 \\
-1,165\end{array}$ \\
\hline Social Sensitivity &, 027 & 2,349 & & & \\
\hline $\begin{array}{l}\text { Social } \\
\text { Control }\end{array}$ &, 164 & $16,597 * * *$ & $\begin{array}{l}\text { Secure } \\
\text { Fearful } \\
\text { Dismissing } \\
\text { Preoccupied }\end{array}$ & $\begin{array}{l}.398 \\
-.001 \\
-.017 \\
-.145\end{array}$ & $\begin{array}{l}7,224 * * * \\
-, 015 \\
-, 326 \\
-2,825 *\end{array}$ \\
\hline
\end{tabular}

The effects of attachment styles on social skills were examined by a multiple variable regression analysis and result are given in table 2. Result show that attachment styles explain emotional expressivity $(\mathrm{F}=6,882)$ emotional sensitivity $(\mathrm{F}=13.203)$, social expressivity $(\mathrm{F}=9.461)$, social control skills $(\mathrm{F}=16.597)$. Attachment styles do not explain emotional control $(\mathrm{F}=2.059)$ and social sensitivity $(\mathrm{F}=2.349)$. Attachment styles account for $7,5 \%$ of total variance in emotional expressivity, $13,5 \%$ of total variance emotional sensitivity, $10 \%$ of total variance in social expressivity and $16,4 \%$ of total variance in social control. When ttest results with regard to the significance of regression coefficients are examined, it is see that secure attachment style predict emotional expressivity $(t=3,893 \quad \beta=.389)$, emotional sensitivity $(\mathrm{t}=6,953, \beta=.150)$, social expressivity $(\mathrm{t}=5,811, \beta=.332)$ and social control $(\mathrm{t}=7,224, \beta=.398)$ skills to a significant extent. Besides, fearful and dismissing attachment styles have a deterministic power in emotional sensitivity $(t=2,384, \beta=.056 ; t=2,328, \beta=.067)$. 
It is seen that preoccupied style explain social control $(\mathrm{t}=-2,825, \beta=-.145)$. Low social control level is related with preoccupied attachment style.

\section{Discussion and Conclusion}

A significant relation between students ' attachment styles and social skills was found. There found positive significant relation between secure attachment style and emotional expressivity, emotional sensitivity, emotional control, social expressivity and social control scores. Because these people find other people worth loving, reliable and altruistic (Collins \& Read, 1990), they tend to relax by receiving help from other when they face a problem (Grossman \& Grossman, 1998, cited in Kart, 2002; Büyükşahin, 2006). Because they have high self-esteem and enjoy social interaction, individuals with secure attachment styles are likely to have ample opportunities to develop and hone their social skills (Guerrero \& Jones, 2003). There found a negative relation between fearful attachment style scores and social control and emotional expressivity scores and a positive relation between fearful attachment style and social sensitivity scores. No significant relation was found between other attachment styles and social skills scores. Considering that people with fearful attachment style do not trust themselves but others (Bartholomew \& Horowitz, 1991), it is not surprising that they are open to social sensitivity. The study by Deniz, Hamarta and Ari (2005) supports this finding. This study found that secure attachment styles between emotional expressivity, social expressivity, social sensitivity, social control significant correlation. In the same study, they found negative relation between fearful attachment style and emotional expressivity and social control, and a positive significant relation between fearful attachment and social sensitivity.

DiTommaso, Brannen-McNulty, Ross and Burgess (2002) found that significant relation between secure attachment scores and emotional expressivity, emotional sensitivity, social expressivity and social control. However, there found a negative relation between secure attachment and social sensitivity. There found a low relation between dismissing attachment and emotional expressivity, social expressivity. Preoccupied attachment showed a weak relation with all social skill sub dimensions except for social sensitivity. There found a low significant relation between fearful attachment style and emotional expressivity, emotional sensitivity, social expressivity and social control. 
It was found out that secure attachment style predicted emotional expressivity, emotional sensitivity, social expressivity, and social control skills. It was also found that fearful and dismissing attachment style predicted emotional sensitivity skill, and preoccupied attachment style predicted social control. Deniz, Hamarta and Ari (2005) found that secure attachment affected emotional expressivity and social expressivity, but it did not affect other sub-dimensions of social skills. Besides, they found that other attachment styles did not affect social skills.

Cassidy, Kirsh and Scolton (1996) found out that dismissing attachment was related with low social sensitivity and social expressivity and that fearful attachment was related with high social sensitivity and rather low social expressivity. It was found out that those who have a preoccupied attachment style have higher social sensitivity and expressivity scores and that those with secure attachment have low social sensitivity scores and high social expressitivity scores. Besides, it was also determined that those who had dismissed attachment had highest scores and those with preoccupied attachment had the lowest scores in terms of social sensitivtiy. Social expressivity was detached from two positive attachment styles (dismissing and secure) and two negative attachment style (preoccupied and fearful) attachment styles.

Kobak \& Sceery (1988) found out that secure individuals could seek help from others to relax and that they helped others to solve their problems and showed effort to understand others. They saw that those individuals sought social support and gave social support when needed. According to Bartholomew, dismissing people have autonomy and high self-esteem at the expense of lacking feeling of closeness. They have difficulty in telling their problems to others as they do not trust others (Bartholomew \& Horowitz, 1991). Dismissing people have positive ideas about themselves but they have negative ideas about people' s nature (Collins \& Read, 1990). Dismissing people seek support from other when they are under stress; however, they cannot make use of this support efficiently and show avoidance behavior (Ognibene \& Collins, 1998).

\section{Suggestions}

As a result of the study, there found a significant relation between attachment styles and social skills of students attending education faculty and it was determined that attachment styles predicted social skills. Considering this case, teacher trainees can be trained to raise their awareness about attachment styles and development of social skills. Especially, pre- 
school and elementary teacher candidates can be trained to set a good role model for their prospective students.

\section{References}

Ainsworth, M. D. S. (1967). Infancy in Uganda: Patterns of attachment behavior. Retrieved May 13, 2007, from http://www.psychology.sunysb.edu/attachemnt/pdf/mda_ugan ch 20. pdf

Ainsworth, M. D. S. (1989). Attachment beyond infancy. American Psychogist, 44, 709-716

Bartholomew, K., \& Horowitz, L. M. (1991). Attachment styles among young adults: A test of a four- category model. Journal of Personality And Social Psychology, 61, 226-244.

Bowlby, J. (1973). Attachment and lost: Separation. New York: Basic Books.

Bowlby, J. (1980). Attachment and lost: Lost. New York: Random House.

Bowlby, J. (1982). Attachment and Bowlby: Attachment. New York: Basic Books.

Bretherton, I. (1985). Attachment theory: Retrospect and prospect. (I. Bretherton, \& E. Waters Eds). Growing points of attachment theory and research (pp. 3-35). Monographs of the Society for Research in Child Development, 50, (1/2).

Burger, J. M. (2006). Personality. Belmont, CA: Wadsworth Publishing

Büyükşahin, A. (2006). Close relationship attachment: Attachment styles and some relational model of investment research of variables. Unpublished Ph.D. Thesis. Ankara University Institute of Social Sciences.

Cassidy J, Kirsh SJ, Scolton KL, \& Parke RD. (1996).Attachment and representations of peer relationships. Developmental Psychology 32, 892-904.

Collins, N. L., \& Read, S. J. (1990). Adult attachment, working models, and relationship quality in dating couples. Journal of Personality and Social Psychology, 58(4), 644-663.

Collins, N. L. (1996). Working models of attachment: Implications for explanation, emotion, and behavior. Journal of Personality and Psychology, 71(4), 810-832

Cooper, M. L., Shaver F. R. \& Collins, N. L. (1998). Attachment styles, emotion regulation, and adjustment in adolescence. Journal of Personality and Social Psychology, 74(5), 1380-1397.

Deniz, E. (2002). Unvestigation of decision making strategies and social skills level of university students with respect to ta-dominant ego states and some personal characteristics. Unpublished PhD Dissertation, Selcuk University, Institute of Social Sciences. 
Deniz, E., Hamarta, E., \& Ari, R. (2005). An investigation of social skills and loneliness level of university students with respect to their attachment styles in a sample of turkish students. Social Behavior and Personality, 33 (1), 19-32.

DiTommaso „E., Brannen-McNulty C., Ross L.\& Burgess M. (2002). Attachment styles, social skills and loneliness in young adults. Personality and Individual Differences, 35 $303-312$

Ekinci, Y. (2006). Elementary school administrators teachers' job satisfaction and job stress on social skill levels comparison. Unpublished Master's Thesis. Gazinantep University Institute of Social Sciences.

Feeney, J. D. (1998). Adult attachment and relationship-centered anxiety responses to physical and emotional distancing. In Jeffry A. Simpson W. Steven Rholes (eds). Attachment Theory and Close Relationships. The Guilford Pres New York-London.

Griffin, D., \& Bartholomew, K. (1994). Metaphysis of measurement: The case of adult attachment. In K. Bartholomew \& D. Perlman (Eds). Advances in Personal Relationships, Vol. 5: Attachment Processes in Adulthood (pp. 17-52). London: Jessica Kingsley.

Hazan, C., \& Shaver, P. R. (1987). Conceptualizing romantic love as an attachment process. Journal of Personality and Social Psychology, 52, 511-524.

Kart, M. (2002). Some cognitive processes connection adult attachment styles : A study of the health care personel. Unpublished PhD Dissertation, Ankara University, Institute of Social Sciences.

Kobak, R. R., \& Sceery, A. (1988). Attachment in late adolescence: Working models, affect regulation, and perceptions of self and others. Child Development, 59, 135-146.

Lieberman, A. F. (1977). Preschoolers ' competence with a peer: Relations with attachment and peer experience. Child Development, 48(4), 1277-1287.

Ognibene, T.C. \& Collins, N.L. (1998). Adult attachment styles, perceived social support and coping strategies. Journal of Social and Personal Relationships June. 15(3), 323-345.

Posada, G., Carbonell, O. A, Alzate, G., \& Plata, S. J. (2004). Through colombian lenses: Etneographic and conventional anayses of maternal care and their associations with secure base behavior. Developmental Psychology, 40(4), 508-518.

Riggio R. E. (1986). Assessment of basic social skills. Journal of Personality And Social Psychology, 51(3), $649-660$. 
Sümer, N., \& Güngör, D. (1999). Psychometric assessment of adult attachment styles and cross- cultural comparison of scales on which the turkish sample. Turkish Journal of Psychology . 14 (43), 35-62.

Yüksel, G. (1997). Effect of social skill education on social skill level of university students. Unpublished PhD Dissertation, Gazi University, Institute of Educational Sciences. 